\title{
Review Article \\ The Role of Vitamin D in Primary Biliary Cirrhosis: Possible Genetic and Cell Signaling Mechanisms
}

\author{
Khanh vinh quốc Lương and Lan Thi Hoàng Nguyễn \\ Vietnamese American Medical Research Foundation, 14971 Brookhurst Street, Westminster, CA 92683, USA \\ Correspondence should be addressed to Khanh vinh quốc Lương; lng2687765@aol.com
}

Received 26 June 2012; Revised 8 November 2012; Accepted 12 November 2012

Academic Editor: P. Malfertheiner

Copyright (C) 2013 K. V. Q. Lương and L. T. H. Nguyễn. This is an open access article distributed under the Creative Commons Attribution License, which permits unrestricted use, distribution, and reproduction in any medium, provided the original work is properly cited.

\begin{abstract}
Primary biliary cirrhosis (PBC) is an immune-mediated chronic inflammatory disease of the liver of unknown etiology. Vitamin $\mathrm{D}$ deficiency is highly prevalent in patients with PBC, and many studies have demonstrated the significant effect of calcitriol on liver cell physiology. Vitamin D has antiproliferative and antifibrotic effects on liver fibrosis. Genetic studies have provided an opportunity to determine which proteins link vitamin D to PBC pathology (e.g., the major histocompatibility complex class II molecules, the vitamin D receptor, toll-like receptors, apolipoprotein E, Nramp1, and cytotoxic T lymphocyte antigen-4). Vitamin D also exerts its effect on PBC through cell signaling mechanisms, that is, matrix metalloproteinases, prostaglandins, reactive oxygen species, and the transforming growth factor betas. In conclusion, vitamin D may have a beneficial role in the treatment of PBC. The best form of vitamin $\mathrm{D}$ for use in the $\mathrm{PBC}$ is calcitriol because it is the active form of vitamin $\mathrm{D}_{3}$ metabolite, and its receptors are present in the sinusoidal endothelial cells, Kupffer cells, and stellate cells of normal livers, as well as in the biliary cell line.
\end{abstract}

\section{Introduction}

Primary biliary cirrhosis (PBC) is an immune-mediated chronic inflammatory disease of the liver of unknown etiology, and its progressive destruction of the bile duct leads to fibrosis and liver cirrhosis. There is evidence of aberrations in the vitamin D-endocrine system in PBC patients. Skeletal demineralization and low serum concentrations of 25-hydroxyvitamin $\mathrm{D}_{3}$ (25OHD) were observed in patients with PBC [1-4]. Vitamin-D absorption was reduced in PBC patients and correlated with the amount of fecal fat [5-7]. Many studies have shown a significant effect of calcitriol on liver cell physiology. Calcitriol increases intracellular $\mathrm{Ca}^{2+}$ in rat hepatocytes [8] and controls DNA polymerase $\alpha$ activity, as well as cytoplasmic and nuclear protein kinase activity, promoting normal liver recovery after partial hepatectomy in rats [9]. Vitamin D was also shown to have a detoxifying effect in human primary cultured hepatocytes by increasing the expression of $\mathrm{P}_{450}$ cytochromes (i.e., CYP3A4, CYP2B6, and CYP2C9) [10]. Some studies failed to detect VDR levels in the liver [11, 12]; however, Gascon-Barré et al. [13] demonstrated that human, rat, and mouse hepatocytes express very low nuclear vitamin D receptor (nVDR) mRNA and protein levels. In contrast, the sinusoidal endothelial, Kupffer, and stellate cells of normal livers, as well as the biliary cell line and rat hepatic neonatal epithelial cells, clearly expressed both nVDR mRNA and protein. Berger et al. [14] demonstrated that calcitriol receptors were localized in the nucleus and widely distributed in normal human tissues, including those of the liver, kidney, thyroid, adrenal glands, gastrointestinal tract, breast, and skin. The calcitriol-binding proteins were present in liver nuclei isolated from mice, rabbits, chickens, and cultured rat hepatocytes [15]. A major metabolite of the vitamin $\mathrm{D}$ analog $1 \alpha$-hydroxyvitamin $\mathrm{D}_{2}, 1 \alpha, 24(\mathrm{~S})$-hydroxyvitamin $\mathrm{D}_{2}$, was identified in human liver cells in culture and binds strongly to the VDR [16]. Another report demonstrated the presence of VDR mRNA and protein in the livers of rats during all periods of the rats' lives [17]. Furthermore, VDR ligands have the potential to prevent a cholestasis-induced inflammatory response. In a mouse model of cholestasis, calcitriol treatment altered the expression of the genes involved in bile acid synthesis and transport in the liver and also suppressed the mRNA expression of proinflammatory cytokines 
in the liver resulting in decreased plasma levels of proinflammatory cytokines [18]. It has been suggested that proliferating cholangiocytes play a key role in chronic cholestasis liver diseases that are characterized by biliary fibrosis [19]. Calcitriol protects liver cells during cholestasis by inhibiting CYP7A1 mRNA expression and bile acid synthesis [20], and both in vitro and in vivo models have demonstrated calcitriol's antiproliferative and antifibrotic effects on liver fibrosis [21]. Another link of $\mathrm{PBC}$ to vitamin $\mathrm{D}$ may be the observation that $\mathrm{PBC}$ has seasonal variation; there was a marked peak for diagnoses of $\mathrm{PBC}$ in the month of June [22]. Furthermore, high prevalence for fatigue was reported in $\mathrm{PBC}$ patients. AlHarthy et al. [23] demonstrated that fatigue appeared to have improved fatigue score in PBC patients taking calcium and vitamin $\mathrm{D}$, whereas biochemical response to ursodeoxycholic acid (UDCA) treatment was not associated with lower fatigue score. These findings suggest that vitamin $\mathrm{D}$ may have a role in PBC. Therefore, we will discuss the role of vitamin D in $\mathrm{PBC}$ with possible genetic and cell signaling mechanisms.

\section{Genetic Factors Related to Vitamin D in Primary Biliary Cirrhosis}

Studies have suggested that several genes in the major histocompatibility complex (MHC) region promote susceptibility to $\mathrm{PBC}$. Located in the $\mathrm{MHC}$ region, human leukocyte antigen (HLA) genes have been implicated in PBC susceptibility. A significant $D R w 8$ allele was found to be increased in patients with $\mathrm{PBC}$ compared with controls [24], and the $D R B 1^{*}-0801-D Q A 1^{*} 0401-D Q B 1^{*} 0402$ haplotype was a marker of disease progression but not of initial susceptibility [25]. A strong association between $\mathrm{PBC}$ and the $D P B 1^{*} 0301$ allele was found in a German population [26]. Although an association between the $D P B 1^{*} 0501$ allele and $\mathrm{PBC}$ was demonstrated in Japanese patients [27], this association was not observed in the German population [26]; this discrepancy is due to differences in the distribution of $D P B 1$ alleles in both ethnic groups [28]. An association with the $D R B 1^{*} 08$ allele was found in German, Spanish, Swedish, and American populations with $\mathrm{PBC}$ [29], whereas the reported association with $\mathrm{PBC}$ is with $D R B 1^{*} 0803$ in the Japanese population [30]. Significant associations were found with $\mathrm{PBC}$ susceptibility for the $D R B 1^{*} 0803-D Q B 1^{*} 0601$ and $D R B 1^{*} 0405$ $D Q B 1^{*} 0401$ haplotypes; in contrast, significant protective associations were found between $\mathrm{PBC}$ and the $D R B 1^{*} 1302$ $D Q B 1^{*} 0604$ haplotype and $D R B 1^{*} 1101-D Q B 1^{*} 0301$ haplotypes in the Japanese population [31]. These data show that there are HLA class II alleles associated with susceptibility to and protection from $\mathrm{PBC}$ and that these differ between ethnic groups. Calcitriol is known to stimulate phagocytosis but suppresses MHC class II antigen expression in human mononuclear phagocytes [32,33]. Calcitriol also decreases interferon-gamma-induced HLA-DR antigen expression in normal and transformed human keratinocytes $[34,35]$. These findings suggest that calcitriol may have an effect on PBC through suppressing the expression of MHC class II antigens.

Genetic studies provide an opportunity to link molecular variations with epidemiological data. DNA sequence variations, such as polymorphisms, exert both modest and subtle biological effects on the molecules. Vitamin D exhibits immunomodulatory and antiproliferative effects through the VDR in diseases. There is an association between BsmI polymorphisms of the VDR and PBC in German, Hungarian, Japanese, Italian, and Chinese patients [36-40]. The $B B$ genotype contributes to the risk of PBC development. In the Polish population, BsmI and TaqI polymorphisms were associated with the presence of advanced fibrosis and liver cirrhosis with the diagnosis of $\mathrm{PBC}$ [41]. In addition, VDR gene polymorphisms were found to be associated with osteoporosis, in which VDR polymorphisms were predictive of decreased bone mineral density in PBC patients $[42,43]$. These reports suggested that alterations in VDR function may play a role in PBC.

Toll-like receptors (TLRs) are a group of glycoproteins that function as surface transmembrane receptors and are involved in the innate immune responses to exogenous pathogenic microorganisms. Substantial evidence points to the importance of TLRs in the pathogenesis and outcome of PBC. Monocytes from $\mathrm{PBC}$ patients appear more sensitive to signaling via select TLRs, resulting in the secretion of selective proinflammatory cytokines [44]. The expression of TLR-3 was markedly increased in biliary epithelial cells (BECs) at ductular reaction sites in liver diseases, including PBC [45]. TLR-3 and type I interferon (IFN) signaling pathways are activated in both the portal tract and parenchyma in earlystage PBC [46]. In addition, the bile duct epithelial cells of PBC liver tissues markedly expressed TLR-4, which was also observed in the periportal hepatocytes of PBC liver tissues, and its expression extended to interlobular hepatocytes in advanced-stage PBC [47]. The expression of TLR-4 and the activation of the natural killer NF- $\kappa \mathrm{B}$ transcription factor were significantly enhanced in the liver tissues of $\mathrm{PBC}$ patients $[48,49]$ and destroyed autologous BECs in the presence of INF- $\alpha$ synthesized by TLR-3 ligand-stimulated monocytes [50]. Furthermore, the CpG motif induces the secretion of antimitochondrial antibodies in peripheral blood mononuclear cells and also upregulates the B-cell expression of TLR-9 in patients with PBC [51]. The 2848 AA TLR-9 genotype influences the immune response to the CpG motif and contributes to hyper-IgM syndrome in PCB [52]. Vitamin D deficiency increases the expression of hepatic mRNA levels of TLR-2, TLR-4, and TLR-9 in obese rats [53]; however, calcitriol suppresses the expression of TLR- 2 and TLR- 4 protein and mRNA in human monocytes and triggers hyporesponsiveness to pathogen-associated molecular patterns [54]. Calcitriol has also been shown to downregulate intracellular TLR-2, TLR-4, and TLR-9 expression in human monocytes [55]. TLR activation results in the expression of the VDR and $1 \alpha$-vitamin D hydroxylase in human monocytes [56]. In addition, calcitriol can increase the vitamin-D-induced expression of cathelicidin in bronchial epithelial cells [57] and may enhance the production of cathelicidin LL-37 [58]. The addition of a VDR antagonist has been shown to inhibit the induction of cathelicidin mRNA by more than $80 \%$, which consequently reduces the protein expression of this antimicrobial agent by approximately 70\% [57]. Biliary epithelial cells show intense immunereactivity to cathelicidin and to the VDR. In cultured biliary epithelial cells, endogenous bile 
salt chenodeoxycholic acid and therapeutic bile salt UDCA induce cathelicidin expression through two different nuclear receptors, such as the farnesoid X receptor and VDR [59]. These findings indicate that bile salt may contribute to biliary tract sterility by controlling epithelial cell innate immunity and combining bile salt with vitamin $\mathrm{D}$ which would increase therapeutic efficacy in inflammatory biliary disease. Taken together, vitamin $\mathrm{D}$ may have a role in $\mathrm{PBC}$ patients by modifying TLR pathways.

Apolipoprotein E (ApoE) has important functions in systemic and local lipid transport. In PBC, serum ApoE was increased and partly contributed to the decrease in the levels of hepatic triglyceride lipase [60,61]. In addition, a close relationship existed between the ratio of ApoE to Apo $A_{1}$ and plasma bile salt concentration [62]. The ApoE $\varepsilon 4$ allele has been suggested to be a marker of disease severity in $\mathrm{PBC}$ [63]. At the time of diagnosis of $\mathrm{PBC}$, the $\varepsilon 4$ allele carriers were younger, had higher bilirubin and IgG levels, and had a lower prothrombin index compared with $\varepsilon 2$ or $\varepsilon 3$ homozygous allele carriers. The $\varepsilon 4$ allele carriers demonstrated a poor response to UDCA treatment. However, the frequency of the $\varepsilon 2$ allele is overexpressed in patients with $\mathrm{PBC}$ and did not respond to UDCA treatment compared with $\varepsilon 4$ allele carriers in the Finnish population [64]. In contrast, the ApoE4 allele is reported to be associated with decreased bone mass in postmenopausal Japanese women [65]. The common ApoE polymorphism has a complex effect on bone metabolism in peri-menopausal Danish women; namely, those with ApoE2 have a lower rate of bone mineral loss in the femoral neck and hip regions compared with other women, whereas those with ApoE4 gain more bone mineral than other women [66]. Calcitriol has been shown to induce macrophages to exhibit specific saturable receptors for lowdensity lipoprotein (LDL), and acetyl LDL, the LDL receptor of 1,25OHD-induced macrophages, has been found to exhibit specificity for ApoB- and ApoE-containing lipoproteins [67]. In ApoE knockout mice, those with dyslipidemia, high oxidative stress, and pronounced atherosclerosis after unilateral nephrectomy developed less plaque growth and calcification with vitamin $\mathrm{D}$ analog treatment (paricalcitol) compared with healthy controls $[68,69]$. ApoE $\varepsilon 4$, however, is associated with higher serum 25OHD levels [70]. These findings suggested that vitamin D may improve lipid profiles and cholesterol metabolisms in $\mathrm{PBC}$ patients.

Nramp1 plays a critical role in macrophage defenses against intracellular pathogens. The expression of Nramp1 in pathogen-containing phagosomes is associated with enhanced fusion to lysosomes, increased phagosomal acidification, and greater bactericidal activity. The NRAMP1 gene has been shown to regulate the concentration of divalent cations in the phagosomes of macrophages [71], and its antibacterial role may be a result of the extrusion of protons and divalent metal ions from the phagosomal lumen toward the cytoplasm [72]. PMNs are the major site of NRAMP1 expression, followed to a lesser degree by monocytes [73]. The Nramp1 gene has been identified among inbred mouse strains as a factor for host defense against some species of mycobacteria [74]. Moreover, antibodies to a $65 \mathrm{kDa}$ mycobacterial protein were found in patients with PBC $[75,76]$. Graham et al. [77] identified novel alleles at a polymorphic microsatellite repeat region in the human NRAMP1 gene promoter in patients with PBC. However, calcitriol is known to stimulate phagocytosis [32] and affects NRAMP1 transcription and protein expression in maturing phagocytes [78]. Taken together, vitamin $\mathrm{D}$ may have a role in $\mathrm{PBC}$ patients by modifying NRAMP1 transcription and protein expression.

Cytotoxic T lymphocyte antigen-4 (CTLA-4) is involved in the regulation of $\mathrm{T}$ cells and is a coregulatory immunoreceptor that has a broad dampening effect on T-cell responses [79]. The PBC is known to be associated with polymorphisms of the CTLA-4 gene in Chinese [80], Japanese [81], Canadian [82], French [83], America Caucasian [84], and British [85] patients, but not in Brazilian patients [86]. The meta-analysis results suggested that the CTLA- 4 gene may be a risk factor for $\mathrm{PBC}$ in Asians [87-89], whereas the AA genotype may have negative associations with $\mathrm{PBC}$ in Asians $[89,90]$. A deficiency of CTLA-4 causes a severe lymphoproliferative disorder and demonstrates multiorgan autoimmunity, leading to massive tissue destruction and early death [91, 92]. Furthermore, CTLA-4 Ig suppressed a lupuslike illness in mouse models [93]. Nonobese diabetic (NOD) mice treated with CTLA-4 Ig after the onset of insulitis had a reduced incidence of diabetes [94]. However, calcitriol promoted regulatory T-cell profiles by increasing CTLA- 4 and interleukin-10 in mouse colon protein extracts [95]. Calcitriol also stimulated the expression of high levels of CTLA-4 in human $\mathrm{CD}^{+} \mathrm{CD}^{-} 5^{-} \mathrm{T}$ cells [96]. These findings suggested that vitamin $\mathrm{D}$ may have a role in $\mathrm{PBC}$ patients by enhancing CTLA-4 levels.

Table 1 summarizes the genetic factors associated with vitamin $\mathrm{D}$ and $\mathrm{PBC}$.

\section{The Cell Signaling Mechanisms to Vitamin D in Primary Biliary Cirrhosis}

Matrix metalloproteinases (MMPs) are proteolytic enzymes that are responsible for extracellular matrix remodeling and the regulation of leukocyte migration through the extracellular matrix, which is an important factor involved in inflammatory processes and infectious diseases. MMPs are produced by many cell types including lymphocytes, granulocytes, astrocytes, and activated macrophages. $\mathrm{Mdr}^{-/-}$mice develop hepatic lesions resembling primary sclerosing cholangitis and spontaneously progress to severe fibrosis, accompanied by the upregulation of MMP-2, MMP-13, and TIMP1 [97]. Increased serum MMP-1 and -2 were observed in patients with PBC [98-100]. Polymorphism of MMP-3 influences susceptibility to primary sclerosing cholangitis [101]. However, VDR knockout mice had an increased influx of inflammatory cells, phosphoacetylation of NF- $\kappa$ B associated with increased proinflammatory cells, and upregulation of MMP-2, MMP-9, and MMP-12 mRNA and enzyme levels in the lung [102]. The VDR TaqI polymorphism is associated with decreased production of TIMP-1, which is a natural inhibitor of MMP-9 [103]. Calcitriol modulates tissue MMP expression under experimental conditions [104], downregulates MMP-9 levels in keratinocytes, and may attenuate the 


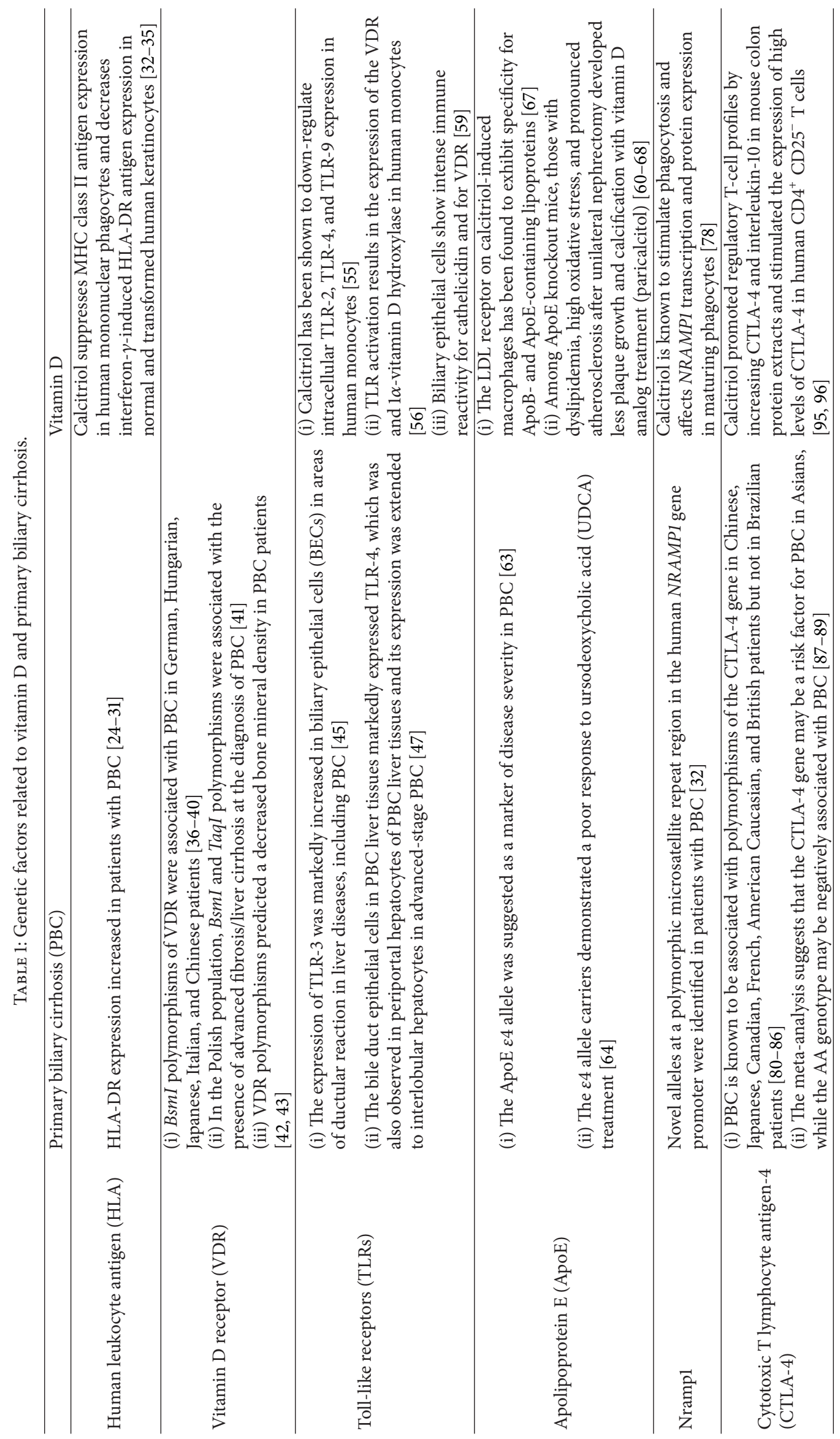


deleterious effects caused by the excessive TNF- $\alpha$-induced proteolytic activity associated with cutaneous inflammation [105]. Calcitriol inhibits both basal and staphylococcusstimulated production of MMP-9 in human blood monocytes and alveolar macrophages [106]. Moreover, a vitamin D analog was reported to reduce the expression of MMP2, MMP-9, VEGF, and PTH-related peptide in Lewis lung carcinoma cells [107]. Calcitriol significantly attenuated $M$. tuberculosis-induced increases in the expression of MMP7 and MMP-10 and suppressed the secretion of MMP-7 by M. tuberculosis-infected PBMCs. MMP-9 gene expression, secretion, and activity were significantly inhibited, irrespective of infection status [108]. In another study, calcitriol suppressed the production of MMPs (MMP-7 and MMP-9) and enhanced the level of TIMP-1 in tuberculosis patients [109]. In another study, the antifibrotic effect of calcitriol was demonstrated by upregulation of MMP-9 enzyme activity, but not the promoter level in HSC [21]. However, vitamin D promotes both up- and downregulation of MMP activity, depending on the specific cell type. These studies suggest that calcitriol may play an important role in the pathological process of $\mathrm{PBC}$ by regulating the level of MMPs and TIMPs.

Prostaglandins (PGs) play a role in inflammatory processes [110]. Cyclooxygenase (COX) participates in the conversion of arachidonic acid into PGs. In chronic bile duct ligation, there is an increase in $\mathrm{PG} \mathrm{E}_{2}$ excretion [111]. Phytohemagglutinin-(PHA-) stimulated enriched monocytes from $\mathrm{PBC}$ patients produced approximately threefold more $P G E_{2}$ than did normal control monocytes and alcoholic cirrhosis monocytes [112]. The monocyte-produced $\mathrm{PG} \mathrm{E}_{2}$ may be responsible for the hyporesponsiveness to PHA observed in $\mathrm{PBC}$ patients [113]. UDCA normalized the defective natural killer activity in $\mathrm{PBC}$ by inhibiting $\mathrm{PG}_{2}$ production [114]. Moreover, $\mathrm{PBC}$ epithelial cells have shown moderate levels of COX-2 expression [115]. Calcitriol has been reported to regulate the expression of several key genes involved in PG pathways, causing a decrease in PG synthesis [116]. Calcitriol and its analogs have also been shown to selectively inhibit the activity of COX-2 [117]; namely, the VDR agonist, elocalcitol, decreased COX-2 expression and $\mathrm{PG}_{2}$ production in benign prostatic hyperplasia cells [118]. These findings suggested that vitamin $\mathrm{D}$ may play a role in modulating the inflammatory process in $\mathrm{PBC}$.

Reactive oxygen species (ROS) have been suggested to play a role in PBC. Lipid peroxidation markers, such as plasma and urinary 8-isoprostane and plasma malondialdehyde (MDA), were significantly increased, whereas plasma total glutathione (GSH) levels were reduced in patients with PBC [119]. UDCA treatment partially corrected plasma GSH status in patients with $\mathrm{PBC}$, and it also decreased portal pressure and increased levels of hepatic GSH and superoxide dismutase (SOD) activity in bile duct-ligated rats [120, 121]. Calcitriol has been reported to exert a receptor-mediated effect on the secretion of hydrogen peroxide by human monocytes [122]. Human monocytes in culture gradually lose their capability to produce superoxide when stimulated; the addition of calcitriol, lipopolysaccharide, or lipoteichoic acid (LTA) restored the ability of stimulated monocytes to produce superoxide and increased oxidative capacity compared with unstimulated monocytes [123]. Calcitriol may also protect nonmalignant prostate cells from oxidative stress-induced cell death by eliminating ROS-induced cellular injuries [124]. Vitamin D metabolites and vitamin D analogs were reported to induce lipoxygenase mRNA expression, lipoxygenase activity, and ROS production in a human bone cell line [125]. Vitamin D may reduce the extent of lipid peroxidation and induce SOD activity of the hepatic antioxidant system in rats $[126,127]$. In addition, calcitriol also enhances intracellular GSH pools and significantly reduces nitrite production induced by lipopolysaccharides (LPS) [128]. These findings suggested that vitamin $\mathrm{D}$ modulates oxidative stress in PBC.

The transforming growth factor-betas (TGF- $\beta$ s) are a group of homologous polypeptides that exert pleiotropic effects on various cell types and stimulate extracellular matrix formation and fibrosis. Northern blot analysis has revealed enhanced expression of TGF- $\beta_{1}$, TGF- $\beta_{2}$, TGF- $\beta_{3}$, and their receptors in human liver cirrhosis [129]; TGF- $\beta_{2}$ has been identified as an actively transcribed TGF- $\beta$ gene during the progression of liver fibrosis in biliary atresia [130]; statistically significant changes in serum TGF- $\beta_{1}$ levels have been demonstrated in common bile duct-ligated rats and in $\mathrm{PBC}$ patients [131-133]; an overexpression of TGF- $\beta_{3}$ has been observed in hepatocytes in PBC patients [134]. However, TGF- $\beta$ has been detected in the majority of specimens from patients with PBC [135]; and a marker of TGF- $\beta$ pathway signaling has been identified in the biliary endothelial cells of patients with posttransplantation recurrence of $\mathrm{PBC}$ [136]. Furthermore, TGF- $\beta$ levels have been reported to be higher in the bone marrow mononuclear cells of PBC patients compared with autoimmune hepatitis type 1 patients [137, 138]. UDCA treatment has reduced TGF- $\beta$ levels in patients with PBC [139]. The inhibition of $\alpha \mathrm{v} \beta 6$ potently inhibits the progression of primary and secondary biliary fibrosis and also blocks TGF- $\beta$ activation [140]. On the other hand, TGF$\beta$ levels have correlated negatively with vitamin D levels; namely, increased TGF- $\beta_{1}$ and platelet counts have been an early indicator of bone marrow fibrosis in patients with vitamin D deficiency [141]. An association has been found between the FokI VDR polymorphism and plasma concentrations of TGF- $\beta$ in patients with type 1 diabetes mellitus [142]. Among diabetic children, higher levels of TGF- $\beta_{1}$ were observed compared with healthy children, and the diabetic carriers of the $f f$ genotype have shown low levels of $25 \mathrm{OHD}$ compared with the carriers of the $F$ allele. Vitamin $\mathrm{D}$ has a significant effect on regulating levels of bioactive TGF- $\beta_{1}$ and appears to affect aspects of the TGF- $\beta_{1}$ signaling pathway in renal tissue [143]. Calcitriol reduces TGF- $\beta_{3}$-induced fibrosis-related gene expression in human leiomyoma cells [144]. Moreover, vitamin D treatment significantly downregulates the free fatty acid-induced expression of TGF- $\beta$ in HSC line LX-2 [145]. These results suggest that vitamin D may participate in the reduction of inflammatory and profibrogenic activity in PBC.

Table 2 summarizes the cell signaling mechanisms to vitamin D in PBC. 


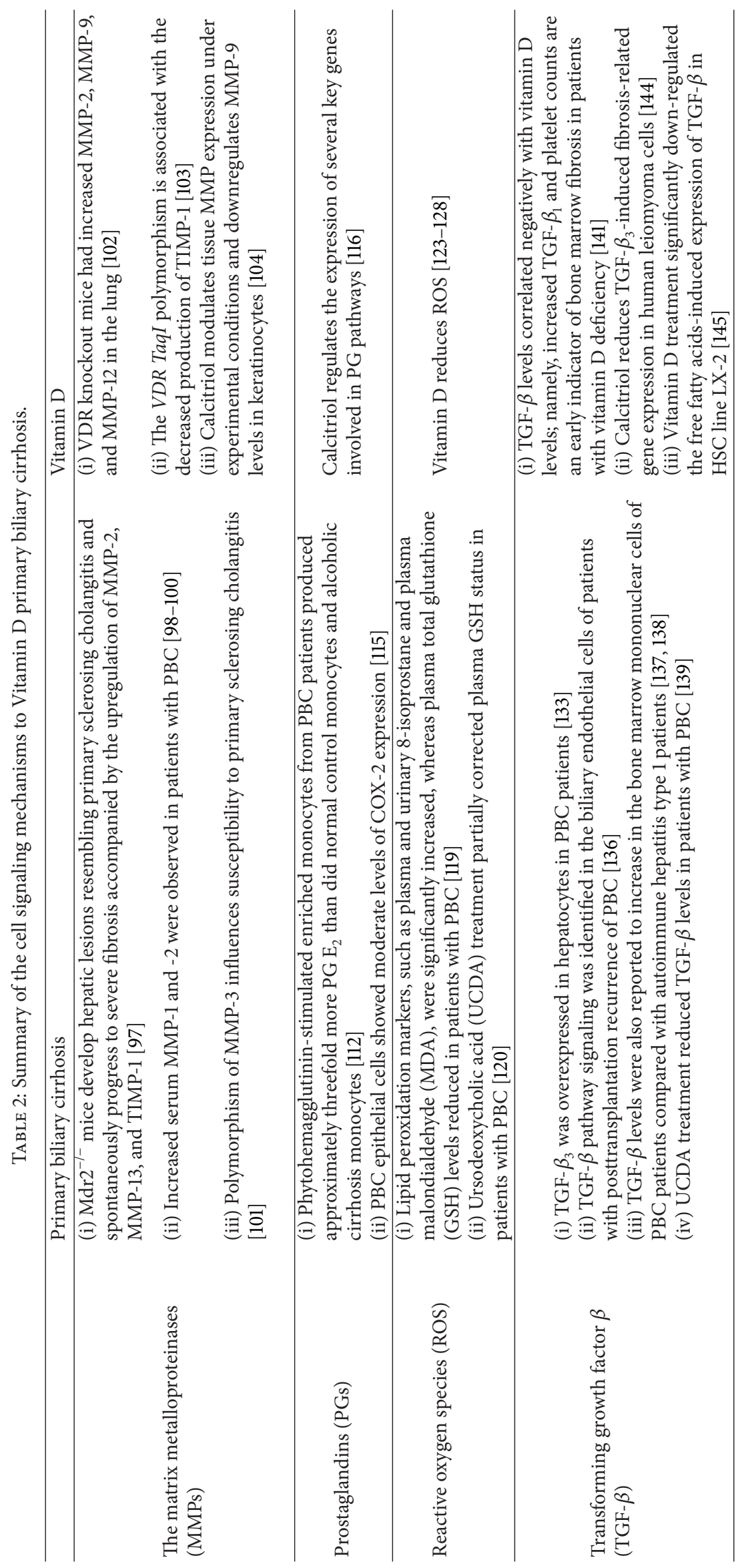




\section{Conclusion}

The relationship between vitamin $\mathrm{D}$ and $\mathrm{PBC}$ has been discussed. Vitamin D may have a beneficial role in PBC and has been demonstrated to have antiproliferative and antifibrotic effects on liver fibrosis. Genetic studies have provided an opportunity to determine which proteins link vitamin D to $\mathrm{PBC}$ pathology. Vitamin D also exerts its effect on $\mathrm{PBC}$ through nongenomic mechanisms. The best form of vitamin $\mathrm{D}$ for use in the treatment of $\mathrm{PBC}$ is calcitriol because it contains the active form of the vitamin $\mathrm{D}_{3}$ metabolite and its receptor is present in the sinusoidal endothelial, Kupffer, and stellate cells of normal livers, as well as in the biliary cell line.

\section{Conflict of Interests}

The authors declare that they no conflict of interests.

\section{References}

[1] J. B. Wagonfeld, B. A. Nemchausky, M. Bolt, J. V. Horst, J. L. Boyer, and I. H. Rosenberg, "Comparison of vitamin D and 25 hydroxy vitamin D in the therapy of primary biliary cirrhosis," The Lancet, vol. 1, no. 7982, pp. 391-394, 1976.

[2] J. S. Reed, S. C. Meredith, B. A. Nemchausky, I. H. Rosenberg, and J. L. Boyer, "Bone disease in primary biliary cirrhosis: reversal of osteomalacia with oral 25-hydroxyvitamin D," Gastroenterology, vol. 78, no. 3, pp. 512-517, 1980.

[3] D. S. Matloff, M. M. Kaplan, R. M. Neer, M. J. Goldberg, W. Bitman, and H. J. Wolfe, "Osteoporosis in primary biliary cirrhosis: effects of 25-hydroxyvitamin D3 treatment," Gastroenterology, vol. 83, no. 1 I, pp. 97-102, 1982.

[4] T. Almdal, O. Schaadt, J. Vesterdal Jorgensen, P. Lindgreen, and L. Ranek, "Vitamin D, parathyroid hormone, and bone mineral content of lumbar spine and femur in primary biliary cirrhosis," Journal of Internal Medicine, vol. 225, no. 3, pp. 207-213, 1989.

[5] E. L. Krawitt, M. J. Grundman, and E. B. Mawer, "Absorption, hydroxylation, and excretion of vitamin $\mathrm{D}_{3}$ in primary biliary cirrhosis," The Lancet, vol. 2, no. 8051, pp. 1246-1249, 1977.

[6] J. M. Barragry, R. G. Long, M. W. France, M. R. Wills, B. J. Boucher, and S. Sherlock, "Intestinal absorption of cholecalciferol in alcoholic liver disease and primary biliary cirrhosis," Gut, vol. 20, no. 7, pp. 559-564, 1979.

[7] A. Danielsson, R. Lorentzon, and S. E. Larsson, "Intestinal absorption and 25-hydroxylation of vitamin $\mathrm{D}$ in patients with primary biliary cirrhosis," Scandinavian Journal of Gastroenterology, vol. 17, no. 3, pp. 349-355, 1982.

[8] D. T. Baran and M. L. Milne, "1,25 Dihydroxyvitamin D increases hepatocyte cytosolic calcium levels. A potential regulator of vitamin D-25-hydroxylase," The Journal of Clinical Investigation, vol. 77, no. 5, pp. 1622-1626, 1986.

[9] R. H. Rixon, R. J. Isaacs, and J. F. Whitfield, "Control of DNA polymerase- $\alpha$ activity in regenerating rat liver by calcium and $1 \alpha, 25(\mathrm{OH})_{2} \mathrm{D}_{3}$," Journal of Cellular Physiology, vol. 139, no. 2, pp. 354-360, 1989.

[10] L. Drocourt, J. C. Ourlin, J. M. Pascussi, P. Maurel, and M. J. Vilarem, "Expression of CYP3A4, CYP2B6, and CYP2C9 is regulated by the vitamin $D$ receptor pathway in primary human hepatocytes," The Journal of Biological Chemistry, vol. 277, no. 28, pp. 25125-25132, 2002.

[11] W. E. Stumpf, M. Sar, F. A. Reid, Y. Tanaka, and H. F. DeLuca, "Target cells for 1,25-dihydroxyvitamin D3 in intestinal tract, stomach, kidney, skin, pituitary, and parathyroid," Science, vol. 206, no. 4423, pp. 1188-1190, 1979.

[12] T. L. Clemens, K. P. Garrett, X. Y. Zhou, J. W. Pike, M. R. Haussler, and D. W. Dempster, "Immunocytochemical localization of the 1,25-dihydroxyvitamin $\mathrm{DM}_{3}$ receptor in target cells," Endocrinology, vol. 122, no. 4, pp. 1224-1230, 1988.

[13] M. Gascon-Barré, C. Demers, A. Mirshahi, S. Néron, S. Zalzal, and A. Nanci, "The normal liver harbors the vitamin D nuclear receptor in nonparenchymal and biliary epithelial cells," Hepatology, vol. 37, no. 5, pp. 1034-1042, 2003.

[14] U. Berger, P. Wilson, R. A. McClelland et al., "Immunocytochemical detection of 1,25-dihydroxyvitamin D receptors in normal human tissues," Journal of Clinical Endocrinology and Metabolism, vol. 67, no. 3, pp. 607-613, 1988.

[15] W. E. Duncan, D. Whitehead, and H. L. Wray, "A 1,25dihydroxyvitamin $\mathrm{D}_{3}$ receptor-like protein in mammalian and avian liver nuclei," Endocrinology, vol. 122, no. 6, pp. 2584-2589, 1988.

[16] S. Strugnell, V. Byford, H. L. J. Makin et al., "1 $1 \alpha, 24($ S)-Dihydroxyvitamin $\mathrm{D}_{2}$ : a biologically active product of $1 \alpha$-hydroxyvitamin $\mathrm{D}_{2}$ made in the human hepatoma, Hep3B," Biochemical Journal, vol. 310, no. 1, pp. 233-241, 1995.

[17] C. Segura, M. Alonso, C. Fraga, T. García-Caballero, C. Diéguez, and R. Pérez-Fernández, "Vitamin D receptor ontogenesis in rat liver," Histochemistry and Cell Biology, vol. 112, no. 2, pp. 163-167, 1999.

[18] M. Ogura, S. Nishida, M. Ishizawa et al., "Vitamin $\mathrm{D}_{3}$ modulates the expression of bile acid regulatory genes and represses inflammation in bile duct-ligated mice," Journal of Pharmacology and Experimental Therapeutics, vol. 328, no. 2, pp. 564-570, 2009.

[19] S. S. Glaser, E. Gaudio, T. Miller, D. Alvaro, and G. Alpini, "Cholangiocyte proliferation and liver fibrosis," Expert Reviews in Molecular Medicine, vol. 11, article e7, 2009.

[20] S. Han and J. Y. L. Chiang, "Mechanism of vitamin D receptor inhibition of cholesterol $7 \alpha$-hydroxylase gene transcription in human hepatocytes," Drug Metabolism and Disposition, vol. 37, no. 3, pp. 469-478, 2009.

[21] S. Abramovitch, L. Dahan-Bachar, E. Sharvit et al., "Vitamin $\mathrm{D}$ inhibits proliferation and profibrotic marker expression in hepatic stellate cells and decreases thioacetamide-induced liver fibrosis in rats," Gut, vol. 60, pp. 1728-1737, 2011.

[22] R. J. Q. McNally, P. W. James, S. Ducker, and O. F. W. James, "Seasonal variation in the patient diagnosis of primary biliary cirrhosis: further evidence for an environmental component to etiology," Hepatology, vol. 54, pp. 2099-2103, 2011.

[23] N. Al-Harthy, T. Kumagi, C. Coltescu, and G. M. Hirschfield, "The specificity of fatigue in primary biliary cirrhosis: evaluation of a large clinic practice," Hepatology, vol. 52, no. 2, pp. 562-570, 2010.

[24] M. P. Manns, A. Bremm, P. M. Schneider et al., "HLA DRw8 and complement $\mathrm{C} 4$ deficiency as risk factors in primary biliary cirrhosis," Gastroenterology, vol. 101, no. 5, pp. 1367-1373, 1991.

[25] P. Donaldson, K. Agarwal, A. Craggs, W. Craig, O. James, and D. Jones, "HLA and interleukin 1 gene polymorphisms in primary biliary cirrhosis: associations with disease progression and disease susceptibility," Gut, vol. 48, no. 3, pp. 397-402, 2001.

[26] J. G. Mella, E. Roschmann, K. P. Maier, and B. A. Volk, "Association of primary biliary cirrhosis with the allele HLADPB1* 0301 in a German population," Hepatology, vol. 21, no. 2, pp. 398-402, 1995. 
[27] T. Seki, K. Kiyosawa, M. Ota et al., "Association of primary biliary cirrhosis with human leukocyte antigen DPB1*0501 in Japanese patients," Hepatology, vol. 18, no. 1, pp. 73-78, 1993.

[28] T. Imanishi, T. Akaza, A. Kimura, K. Tokunaga, and T. Gojobori, "Allele and haplotype frequencies for HLA and complement loci in various ethnic groups," in Proceedings of the 11th International Histocompatibility Workshop and Conference, vol. 1, Yokohama, Japan, November 1991.

[29] P. Invernizzi, "Human leukocyte antigen in primary biliary cirrhosis: an old story now reviving," Hepatology, vol. 54, no. 2, pp. 714-723, 2011.

[30] S. Onishi, T. Sakamaki, T. Maeda et al., "DNA typing of HLA class II genes; DRB1* 0803 increases the susceptibility of Japanese to primary biliary cirrhosis," Journal of Hepatology, vol. 21, no. 6, pp. 1053-1060, 1994.

[31] T. Umemura, S. Joshita, T. Ichijo et al., "Human leukocyte antigen class II molecules confer both susceptibility and progression in Japanese patients with primary biliary cirrhosis," Нераtology, vol. 55, pp. 506-511, 2012.

[32] N. Tokuda and R. B. Levy, "1,25-Dihydroxyvitamin $\mathrm{D}_{3}$ stimulates phagocytosis but suppresses HLA-DR and CD13 antigen expression in human mononuclear phagocytes," Proceedings of the Society for Experimental Biology and Medicine, vol. 211, no. 3, pp. 244-250, 1996.

[33] N. Tokuda, N. Mizuki, M. Kasahara, and R. B. Levy, "1,25dihydroxyvitamin $\mathrm{D}_{3}$ down-regulation of HLA-DR on human peripheral blood monocytes," Immunology, vol. 75, no. 2, pp. 349-354, 1992.

[34] K. Tamaki, A. Saitoh, and Y. Kubota, "1,25-Dihydroxyvitamin $\mathrm{D}_{3}$ decreases the interferon- $\gamma($ IFN- $\gamma$ ) induced HLA-DR expression but not intercellular adhesion molecule 1 (ICAM-1) on human keratinocytes," Regional Immunology, vol. 3, no. 5, pp. 223-227, 1990.

[35] T. Tone, H. Eto, T. Katou, F. Otani, and S. Nishiyama, " $1 \alpha, 25-$ dihydroxy vitamin $\mathrm{D}_{3}$ modulation of HLA-DR mRNA induced by gamma- interferon in cultured epithelial tumor cell lines," Journal of Dermatology, vol. 20, no. 9, pp. 581-584, 1993.

[36] A. Vogel, C. P. Strassburg, and M. P. Manns, "Genetic association of vitamin D receptor polymorphisms with primary biliary cirrhosis and autoimmune hepatitis," Hepatology, vol. 35, no. 1, pp. 126-131, 2002.

[37] B. Halmos, F. Szalay, T. Cserniczky et al., "Association of primary biliary cirrhosis with vitamin D receptor BsmI genotype polymorphism in a Hungarian population," Digestive Diseases and Sciences, vol. 45, no. 6, pp. 1091-1095, 2000.

[38] L. P. Lakatos, É. Bajnok, D. Hegedus, T. Tóth, P. Lakatos, and F. Szalay, "Vitamin D receptor, oestrogen receptor-alpha gene and interleukin-1 receptor antagonist gene polymorphisms in Hungarian patients with primary biliary cirrhosis," European Journal of Gastroenterology and Hepatology, vol. 14, no. 7, pp. 733-740, 2002.

[39] A. Tanaka, S. Nezu, S. Uegaki et al., "Vitamin D receptor polymorphisms are associated with increased susceptibility to primary biliary cirrhosis in Japanese and Italian populations," Journal of Hepatology, vol. 50, no. 6, pp. 1202-1209, 2009.

[40] L. Fan, X. Tu, Y. Zhu et al., "Genetic association of vitamin D receptor polymorphisms with autoimmune hepatitis and primary biliary cirrhosis in the Chinese," Journal of Gastroenterology and Hepatology, vol. 20, no. 2, pp. 249-255, 2005.

[41] A. Kempinska-Podhorecka, E. Wunsch, T. Jarowicz et al., "Vitamin d receptor polymorphisms predispose to primary biliary cirrhosis and severity of the disease in Polish population," Gastroenterology Research and Practice, vol. 2012, Article ID 408723, 8 pages, 2012.

[42] J. E. Springer, D. E. C. Cole, L. A. Rubin et al., "Vitamin D-receptor genotypes as independent genetic predictors of decreased bone mineral density in primary biliary cirrhosis," Gastroenterology, vol. 118, no. 1, pp. 145-151, 2000.

[43] A. Parés, N. Guañabens, and J. Rodés, "Gene polymorphisms as predictors of decreased bone mineral density and osteoporosis in primary biliary cirrhosis," European Journal of Gastroenterology and Hepatology, vol. 17, no. 3, pp. 311-315, 2005.

[44] T. K. Mao, Z. X. Lian, C. Selmi et al., "Altered monocyte responses to defined TLR ligands in patients with primary biliary cirrhosis," Hepatology, vol. 42, no. 4, pp. 802-808, 2005.

[45] M. Nakamura, K. Funami, A. Komori et al., "Increased expression of Toll-like receptor 3 in intrahepatic biliary epithelial cells at sites of ductular reaction in diseased livers," Hepatology International, vol. 2, no. 2, pp. 222-230, 2008.

[46] Y. Takii, M. Nakamura, M. Ito et al., "Enhanced expression of type I interferon and toll-like receptor-3 in primary biliary cirrhosis," Laboratory Investigation, vol. 85, no. 7, pp. 908-920, 2005.

[47] A. P. Wang, K. Migita, M. Ito et al., "Hepatic expression of toll-like receptor 4 in primary biliary cirrhosis," Journal of Autoimmunity, vol. 25, no. 1, pp. 85-91, 2005.

[48] Y. Honda, S. Yamagiwa, Y. Matsuda, M. Takamura, T. Ichida, and Y. Aoyagi, "Altered expression of TLR homolog RP105 on monocytes hypersensitive to LPS in patients with primary biliary cirrhosis," Journal of Hepatology, vol. 47, no. 3, pp. 404-411, 2007.

[49] J. Zhao, S. Zhao, G. Zhou et al., "Altered biliary epithelial cell and monocyte responses to lipopolysaccharide as a TLR ligand in patients with primary biliary cirrhosis," Scandinavian Journal of Gastroenterology, vol. 46, no. 4, pp. 485-494, 2011.

[50] S. Shimoda, K. Harada, H. Niiro et al., "Interaction between Toll-like receptors and natural killer cells in the destruction of bile ducts in primary biliary cirrhosis," Hepatology, vol. 53, no. 4, pp. 1270-1281, 2011.

[51] Y. Moritoki, Z. X. Lian, H. Wulff et al., "AMA production in primary biliary cirrhosis is promoted by the TLR9 ligand CpG and suppressed by potassium channel blockers," Hepatology, vol. 45, no. 2, pp. 314-322, 2007.

[52] K. Kikuchi, Z. X. Lian, Y. Kimura et al., "Genetic polymorphisms of toll-like receptor 9 influence the immune response to CpG and contribute to hyper-IgM in primary biliary cirrhosis," Journal of Autoimmunity, vol. 24, no. 4, pp. 347-352, 2005.

[53] C. L. Roth, C. T. Elfers, D. P. Figlewicz et al., "Vitamin D deficiency in obese rats exacerbates nonalcoholic fatty liver disease and increases hepatic resistin and Toll-like receptor activation," Hepatology, vol. 55, pp. 1103-1111, 2012.

[54] K. Sadeghi, B. Wessner, U. Laggner et al., "Vitamin $\mathrm{D}_{3}$ downregulates monocyte TLR expression and triggers hyporesponsiveness to pathogen-associated molecular patterns," European Journal of Immunology, vol. 36, no. 2, pp. 361-370, 2006.

[55] L. J. Dickie, L. D. Church, L. R. Coulthard, R. J. Mathews, P. Emery, and M. F. McDermott, "Vitamin $\mathrm{D}_{3}$ down-regulates intracellular Toll-like receptor 9 expression and Toll-like receptor 9-induced IL-6 production in human monocytes," Rheumatology, vol. 49, no. 8, Article ID keq124, pp. 1466-1471, 2010. 
[56] P. T. Liu, S. Stenger, H. Li et al., “Toll-like receptor triggering of a vitamin D-mediated human antimicrobial response," Science, vol. 311, no. 5768, pp. 1770-1773, 2006.

[57] S. Yim, P. Dhawan, C. Ragunath, S. Christakos, and G. Diamond, "Induction of cathelicidin in normal and CF bronchial epithelial cells by 1,25-dihydroxyvitamin $\mathrm{D}_{3}$," Journal of Cystic Fibrosis, vol. 6, no. 6, pp. 403-410, 2007.

[58] B. Rivas-Santiago, R. Hernandez-Pando, C. Carranza et al., "Expression of cathelicidin LL-37 during Mycobacterium tuberculosis infection in human alveolar macrophages, monocytes, neutrophils, and epithelial cells," Infection and Immunity, vol. 76, no. 3, pp. 935-941, 2008.

[59] E. D’Aldebert, M. J. Biyeyeme Bi Mve, M. Mergey et al., "Bile salts control the antimicrobial peptide cathelicidin through nuclear receptors in the human biliary epithelium," Gastroenterology, vol. 136, no. 4, pp. 1435-1443, 2009.

[60] S. Koga, Y. Miyata, and H. Ibayashi, "Plasma lipoproteins and apoproteins in primary biliary cirrhosis," Hepatology, vol. 5, no. 2, pp. 286-292, 1985.

[61] H. Hiraoka, S. Yamashita, Y. Matsuzawa et al., "Decrease of hepatic triglyceride lipase levels and increase of cholesteryl ester transfer protein levels in patients with primary biliary cirrhosis: relationship to abnormalities in high-density lipoprotein," Hepatology, vol. 18, no. 1, pp. 103-110, 1993.

[62] C. H. Florén and A. Gustafson, "Apolipoproteins A-I, A-II and E in cholestatic liver disease," Scandinavian Journal of Clinical \& Laboratory Investigation, vol. 45, pp. 103-108, 1985.

[63] C. Corpechot, P. Benlian, V. Barbu, O. Chazouillères, R. E. Poupon, and R. Poupon, "Apolipoprotein E polymorphism, a marker of disease severity in primary biliary cirrhosis?" Journal of Hepatology, vol. 35, no. 3, pp. 324-328, 2001.

[64] M. Vuoristo, M. Färkkilä, H. Gylling et al., "Expression and therapeutic response related to apolipoprotein E polymorphism in primary biliary cirrhosis," Journal of Hepatology, vol. 27, no. 1, pp. 136-142, 1997.

[65] M. Shiraki, Y. Shiraki, C. Aoki et al., "Association of bone mineral density with apolipoprotein E phenotype," Journal of Bone and Mineral Research, vol. 12, no. 9, pp. 1438-1445, 1997.

[66] L. U. Gerdes, P. Vestergaard, A. P. Hermann, and L. Mosekilde, "Regional and hormone-dependent effects of apolipoprotein e genotype on changes in bone mineral in perimenopausal women," Journal of Bone and Mineral Research, vol. 16, no. 10, pp. 1906-1916, 2001.

[67] Z. E. Jouni and D. J. McNamara, "Lipoprotein receptors of HL-60 macrophages: effect of differentiation with tetramyristic phorbol acetate and 1,25-dihydroxyvitamin $\mathrm{D}_{3}$," Arteriosclerosis and Thrombosis, vol. 11, no. 4, pp. 995-1006, 1991.

[68] K. Husain, E. Suarez, A. Isidro, and L. Ferder, "Effects of paricalcitol and enalapril on atherosclerotic injury in mouse aortas," American Journal of Nephrology, vol. 32, no. 4, pp. 296-304, 2010.

[69] L. E. Becker, N. Koleganova, G. Piecha et al., "Effect of paricalcitol and calcitriol on aortic wall remodeling in uninephrectomized ApoE knockout mice," American Journal of Physiology, vol. 300, no. 3, pp. F772-F782, 2011.

[70] P. Huebbe, A. Nebel, S. Siegert et al., "APOE $\varepsilon 4$ is associated with higher vitamin D levels in targeted replacement mice and humans," The FASEB Journal, vol. 25, pp. 3262-3270, 2011.

[71] J. R. Forbes and P. Gros, "Divalent-metal transport by NRAMP proteins at the interface of host-pathogen interactions," Trends in Microbiology, vol. 9, no. 8, pp. 397-403, 2001.
[72] N. Jabado, A. Jankowski, S. Dougaparsad, V. Picard, S. Grinstein, and P. Gros, "Natural resistance to intracellular infections: natural resistance-associated macrophage protein 1 (NRAMP1) functions as a $\mathrm{pH}$-dependent manganese transporter at the phagosomal membrane," Journal of Experimental Medicine, vol. 192, no. 9, pp. 1237-1248, 2000.

[73] M. Cellier, C. Shustik, W. Dalton et al., "Expression of the human NRAMP1 gene in professional primary phagocytes: studies in blood cells and in HL-60 promyelocytic leukemia," Journal of Leukocyte Biology, vol. 61, no. 1, pp. 96-105, 1997.

[74] S. Vidal, M. L. Tremblay, G. Govoni et al., "The Ity/Lsh/Bcg locus: natural resistance to infection with intracellular parasites is abrogated by disruption of the Nrampl gene," Journal of Experimental Medicine, vol. 182, no. 3, pp. 655-666, 1995.

[75] J. O’Donohue, B. McFarlane, A. Bomford, M. Yates, and R. Williams, "Antibodies to atypical mycobacteria in primary biliary cirrhosis," Journal of Hepatology, vol. 21, no. 5, pp. 887889, 1994.

[76] L. Vilagut, A. Parés, O. Viñas, J. Vila, M. T. Jiménez de Anta, and J. Rodés, "Antibodies to mycobacterial $65-\mathrm{kD}$ heat shock protein cross-react with the main mitochondrial antigens in patients with primary biliary cirrhosis," European Journal of Clinical Investigation, vol. 27, no. 8, pp. 667-672, 1997.

[77] A. M. Graham, M. M. Dollinger, S. E. M. Howie, and D. J. Harrison, "Identification of novel alleles at a polymorphic microsatellite repeat region in the human NRAMP1 gene promoter: analysis of allele frequencies in primary biliary cirrhosis," Journal of Medical Genetics, vol. 37, no. 2, pp. 150-152, 2000.

[78] E. A. Roig, E. Richer, F. Canonne-Hergaux, P. Gros, and M. F. M. Cellier, "Regulation of NRAMP1 gene expression by $1 \alpha, 25-$ dihydroxy-vitamin $\mathrm{D}_{3}$ in HL-60 phagocytes," Journal of Leukocyte Biology, vol. 71, no. 5, pp. 890-904, 2002.

[79] E. A. Tivol, A. N. Schweitzer, and A. H. Sharpe, "Costimulation and autoimmunity," Current Opinion in Immunology, vol. 8, pp. 822-830, 1996.

[80] L. Y. Fan, Y. Zhu, R. Q. Zhong et al., "Study on the relationship of CTLA-4 $-318,+49$ polymorphisms with autoimmune hepatitis and primary biliary cirrhosis in a Chinese population," Chinese Journal of Medical Genetics, vol. 21, no. 5, pp. 440-443, 2004 (Chinese).

[81] S. Joshita, T. Umemura, K. Yoshizawa et al., "Association analysis of cytotoxic T-lymphocyte antigen 4 gene polymorphisms with primary biliary cirrhosis in Japanese patients," Journal of Hepatology, vol. 53, no. 3, pp. 537-541, 2010.

[82] B. D. Juran, E. J. Atkinson, J. J. Larson et al., "Carriage of a tumor necrosis factor polymorphism amplifies the cytotoxic T-lymphocyte antigen 4 attributed risk of primary biliary cirrhosis: evidence for a gene-gene interaction," Hepatology, vol. 52, no. 1, pp. 223-229, 2010.

[83] R. Poupon, C. Ping, Y. Chrétien et al., "Genetic factors of susceptibility and of severity in primary biliary cirrhosis," Journal of Hepatology, vol. 49, no. 6, pp. 1038-1045, 2008.

[84] B. D. Juran, E. J. Atkinson, E. M. Schlicht, B. L. Fridley, and K. N. Lazaridis, "Primary biliary cirrhosis is associated with a genetic variant in the 3' flanking region of the CTLA4 gene," Gastroenterology, vol. 135, no. 4, pp. 1200-1206, 2008.

[85] P. Donaldson, S. Veeramani, A. Baragiotta et al., "Cytotoxic T-lymphocyte-associated antigen-4 single nucleotide polymorphisms and haplotypes in primary biliary cirrhosis," Clinical Gastroenterology and Hepatology, vol. 5, no. 6, pp. 755-760, 2007. 
[86] P. L. Bittencourt, S. A. Palácios, A. Q. Farias et al., "Analysis of major histocompatibility complex and CTLA-4 alleles in Brazilian patients with primary biliary cirrhosis," Journal of Gastroenterology and Hepatology, vol. 18, no. 9, pp. 1061-1066, 2003.

[87] R. R. Chen, Z. Y. Han, J. G. Li et al., "Cytotoxic T-lymphocyte antigen 4 gene $+49 \mathrm{~A} / \mathrm{G}$ polymorphism significantly associated with susceptibility to primary biliary cirrhosis: a meta-analysis," Journal of Digestive Diseases, vol. 12, pp. 428-435, 2011.

[88] Q. Huang, F. Shao, C. Wang, L. J. Qiu, Y. G. Hu, and J. H. Yu, "Association between CTLA-4 Exon-1 +49A $>$ G polymorphism and primary biliary cirrhosis risk: a meta-analysis," Archives of Medical Research, vol. 42, no. 3, pp. 235-238, 2011.

[89] Y. Miyake, F. Ikeda, A. Takaki, K. Nouso, and K. Yamamoto, " $+49 \mathrm{~A} / \mathrm{G}$ polymorphism of cytotoxic T-lymphocyte antigen 4 gene in type 1 autoimmune hepatitis and primary biliary cirrhosis: a meta-analysis," Hepatology Research, vol. 41, no. 2, pp. 151-159, 2011.

[90] M. Li, H. Zheng, T. Li, P. Gao, X. L. Zhang, and D. W. Liu, "Cytotoxic T-lymphocyte associated antigen-4 gene polymorphisms and primary biliary cirrhosis: a systematic review," Journal of Gastroenterology and Hepatology, vol. 27, no. 7, pp. 1159-1166, 2012.

[91] P. Waterhouse, J. M. Penninger, E. Timms et al., "Lymphoproliferative disorders with early lethality in mice deficient in Ctla-4," Science, vol. 270, no. 5238, pp. 985-988, 1995.

[92] E. A. Tivol, F. Borriello, A. N. Schweitzer, W. P. Lynch, J. A. Bluestone, and A. H. Sharpe, "Loss of CTLA-4 leads to massive lymphoproliferation and fatal multiorgan tissue destruction, revealing a critical negative regulatory role of CTLA-4," Immunity, vol. 3, no. 5, pp. 541-547, 1995.

[93] B. K. Finck, P. S. Linsley, and D. Wofsy, "Treatment of murine lupus with CTLA4Ig," Science, vol. 265, no. 5176, pp. 1225-1227, 1994.

[94] D. J. Lenschow, S. C. Ho, H. Sattar et al., "Differential effects of anti-B7-1 and anti-B7-2 monoclonal antibody treatment on the development of diabetes in the nonobese diabetic mouse," Journal of Experimental Medicine, vol. 181, no. 3, pp. 1145-1155, 1995.

[95] C. Daniel, N. A. Sartory, N. Zahn, H. H. Radeke, and J. M. Stein, "Immune modulatory treatment of trinitrobenzene sulfonic acid colitis with calcitriol is associated with a change of a $\mathrm{T}$ helper (Th) 1/Th17 to a Th2 and regulatory T cell profile," Journal of Pharmacology and Experimental Therapeutics, vol. 324, no. 1, pp. 23-33, 2008.

[96] L. E. Jeffery, F. Burke, M. Mura et al., "1,25-Dihydroxyvitamin D3 and IL-2 combine to inhibit T cell production of inflammatory cytokines and promote development of regulatory $\mathrm{T}$ cells expressing CTLA-4 and FoxP3," Journal of Immunology, vol. 183, no. 9, pp. 5458-5467, 2009.

[97] Y. Popov, E. Patsenker, P. Fickert, M. Trauner, and D. Schuppan, "Mdr2 (Abcb4) $)^{-/-}$mice spontaneously develop severe biliary fibrosis via massive dysregulation of pro- and antifibrogenic genes," Journal of Hepatology, vol. 43, no. 6, pp. 1045-1054, 2005.

[98] J. Holoman, J. Glasa, S. Galbavy et al., "Serum markers of liver fibrogenesis, and liver histology findings in patients with chronic liver diseases.," Bratislavske Lekarske Listy, vol. 103, no. 2, pp. 70-75, 2002.

[99] N. Fujimoto, N. Mouri, K. Iwata, E. Ohuchi, Y. Okada, and T. Hayakawa, "A one-step sandwich enzyme immunoassay for human matrix metalloproteinase $2(72-\mathrm{kDa}$ gelatinase/type IV collagenase) using monoclonal antibodies," Clinica Chimica Acta, vol. 221, no. 1-2, pp. 91-103, 1993.
[100] R. C. Benyon, J. P. Iredale, S. Goddard, P. J. Winwood, and M. J. P. Arthur, "Expression of tissue inhibitor of metalloproteinases 1 and 2 is increased in fibrotic human liver," Gastroenterology, vol. 110, no. 3, pp. 821-831, 1996.

[101] J. Satsangi, R. W. G. Chapman, N. Haldar et al., "A functional polymorphism of the stromelysin gene (MMP-3) influences susceptibility to primary sclerosing cholangitis," Gastroenterology, vol. 121, no. 1, pp. 124-130, 2001.

[102] I. K. Sundar, J. W. Hwang, S. Wu, J. Sun, and I. Rahman, "Deletion of vitamin D receptor leads to premature emphysema/ COPD by increased matrix metalloproteinases and lymphoid aggregates formation," Biochemical and Biophysical Research Communications, vol. 406, no. 1, pp. 127-133, 2011.

[103] P. M. Timms, N. Mannan, G. A. Hitman et al., "Circulating MMP9, vitamin D and variation in the TIMP-1 response with VDR genotype: mechanisms for inflammatory damage in chronic disorders?" The Quarterly Journal of Medicine, vol. 95, no. 12, pp. 787-796, 2002.

[104] D. D. Dean, Z. Schwartz, J. Schmitz et al., "Vitamin D regulation of metalloproteinase activity in matrix vesicles," Connective Tissue Research, vol. 35, no. 1-4, pp. 331-336, 1996.

[105] K. Bahar-Shany, A. Ravid, and R. Koren, "Upregulation of MMP-9 production by TNF $\alpha$ in keratinocytes and its attenuation by vitamin D," Journal of Cellular Physiology, vol. 222, no. 3, pp. 729-737, 2010.

[106] S. Lacraz, J. M. Dayer, L. Nicod, and H. G. Welgus, "1,25Dihydroxyvitamin $\mathrm{D}_{3}$ dissociates production of interstitial collagenase and $92-\mathrm{kDa}$ gelatinase in human mononuclear phagocytes," The Journal of Biological Chemistry, vol. 269, no. 9, pp. 6485-6490, 1994.

[107] K. Nakagawa, Y. Sasaki, S. Kato, N. Kubodera, and T. Okano, "22-Oxa-1 $\alpha, 25$-dihydroxyvitamin $\mathrm{D}_{3}$ inhibits metastasis and angiogenesis in lung cancer," Carcinogenesis, vol. 26, no. 6, pp. 1044-1054, 2005.

[108] A. Coussens, P. M. Timms, B. J. Boucher et al., " $1 \alpha$,25-dihydroxyvitamin $\mathrm{D}_{3}$ inhibits matrix metalloproteinases induced by Mycobacterium tuberculosis infection," Immunology, vol. 127, no. 4, pp. 539-548, 2009.

[109] S. P. Anand and P. Selvaraj, "Effect of 1, 25 dihydroxyvitamin $D_{3}$ on matrix metalloproteinases MMP-7, MMP-9 and the inhibitor TIMP-1 in pulmonary tuberculosis," Clinical Immunology, vol. 133, no. 1, pp. 126-131, 2009.

[110] E. Ricciotti and G. A. Fitzgerald, "Prostaglandins and inflammation," Arteriosclerosis, Thrombosis, and Vascular Biology, vol. 31, no. 5, pp. 986-1000, 2011.

[111] M. Criado, O. Flores, F. Hidalgo, J. M. López-Novoa, and A. Sánchez-Rodríguez, "Interaction between prostanoids and nitric oxide in the control of tubular function in rats with chronic bile duct ligation," Canadian Journal of Physiology and Pharmacology, vol. 77, no. 2, pp. 111-117, 1999.

[112] M. Chiricolo, M. Lenzi, F. Bianchi et al., "Immune dysfunction in primary biliary cirrhosis. II. Increased production of prostaglandin E," Scandinavian Journal of Immunology, vol. 30, no. 3, pp. 363-367, 1989.

[113] F. Licastro, M. Lenzi, M. Chiricolo et al., "Immune dysfunction in primary biliary cirrhosis (PBC): I. Increased sensitivity of PHA stimulated lymphocyte cultures to indomethacin," Journal of Clinical and Laboratory Immunology, vol. 23, no. 1, pp. 19-23, 1987.

[114] Y. Nishigaki, H. Ohnishi, H. Moriwaki, and Y. Muto, "Ursodeoxycholic acid corrects defective natural killer activity by 
inhibiting prostaglandin E2 production in primary biliary cirrhosis," Digestive Diseases and Sciences, vol. 41, no. 7, pp. 14871493, 1996.

[115] N. Hayashi, H. Yamamoto, N. Hiraoka et al., "Differential expression of cyclooxygenase-2 (COX-2) in human bile duct epithelial cells and bile duct neoplasm," Hepatology, vol. 34, no. 4, pp. 638-650, 2001.

[116] J. Moreno, A. V. Krishnan, S. Swami, L. Nonn, D. M. Peehl, and D. Feldman, "Regulation of prostaglandin metabolism by calcitriol attenuates growth stimulation in prostate cancer cells," Cancer Research, vol. 65, no. 17, pp. 7917-7925, 2005.

[117] R. Aparna, J. Subhashini, K. R. Roy et al., "Selective inhibition of cyclooxygenase-2 (COX-2) by $1 \alpha, 25$-dihydroxy-16-ene-23yne-vitamin $\mathrm{D}_{3}$, a less calcemic vitamin $\mathrm{D}$ analog," Journal of Cellular Biochemistry, vol. 104, no. 5, pp. 1832-1842, 2008.

[118] G. Penna, B. Fibbi, S. Amuchastegui et al., "The vitamin D receptor agonist elocalcitol inhibits IL-8-dependent benign prostatic hyperplasia stromal cell proliferation and inflammatory response by targeting the RhoA/Rho kinase and NF-kB pathways," Prostate, vol. 69, no. 5, pp. 480-493, 2009.

[119] A. Aboutwerat, P. W. Pemberton, A. Smith et al., "Oxidant stress is a significant feature of primary biliary cirrhosis," Biochimica et Biophysica Acta, vol. 1637, no. 2, pp. 142-150, 2003.

[120] P. W. Pemberton, A. Aboutwerat, A. Smith, and T. W. Warnes, "Ursodeoxycholic acid in primary biliary cirrhosis improves glutathione status but fails to reduce lipid peroxidation," Redox Report, vol. 11, no. 3, pp. 117-123, 2006.

[121] Y. Y. Yang, Y. T. Huang, K. C. Lee et al., "Chronic administration of ursodeoxycholic acid decreases portal pressure in rats with biliary cirrhosis," Clinical Science, vol. 116, no. 1, pp. 71-79, 2009.

[122] M. S. Cohen, D. E. Mesler, R. G. Snipes, and T. K. Gray, "1,25Dihydroxyvitamin $\mathrm{D}_{3}$ activates secretion of hydrogen peroxide by human monocytes," Journal of Immunology, vol. 136, no. 3, pp. 1049-1053, 1986.

[123] R. Levy and H. L. Malech, "Effect of 1,25-dihydroxyvitamin $\mathrm{D}_{3}$, lipopolysaccharide, or lipoteichoic acid on the expression of NADPH oxidase components in cultured human monocytes," Journal of Immunology, vol. 147, no. 9, pp. 3066-3071, 1991.

[124] B. Y. Bao, H. J. Ting, J. W. Hsu, and Y. F. Lee, "Protective role of $1 \alpha, 25$-dihydroxyvitamin $\mathrm{D}_{3}$ against oxidative stress in nonmalignant human prostate epithelial cells," International Journal of Cancer, vol. 122, no. 12, pp. 2699-2706, 2008.

[125] D. Somjen, S. Katzburg, M. Grafi-Cohen, E. Knoll, O. Sharon, and G. H. Posner, "Vitamin D metabolites and analogs induce lipoxygenase mRNA expression and activity as well as reactive oxygen species (ROS) production in human bone cell line," Journal of Steroid Biochemistry and Molecular Biology, vol. 123, no. 1-2, pp. 85-89, 2011.

[126] S. Sardar, A. Chakraborty, and M. Chatterjee, "Comparative effectiveness of vitamin $\mathrm{D}_{3}$ and dietary vitamin $\mathrm{E}$ on peroxidation of lipids and enzymes of the hepatic antioxidant system in sprague-Dawley rats," International Journal for Vitamin and Nutrition Research, vol. 66, no. 1, pp. 39-45, 1996.

[127] N. George, T. Peeyush Kumar, S. Antony, S. Jayanarayanan, and C. S. Paulose, "Effect of vitamin $\mathrm{D}_{3}$ in reducing metabolic and oxidative stress in the liver of streptozotocin-induced diabetic rats," British Journal of Nutrition, vol. 108, no. 8, pp. 1410-1418, 2012.

[128] E. Garcion, L. Sindji, G. Leblondel, P. Brachet, and F. Darcy, "1,25-dihydroxyvitamin $\mathrm{D}_{3}$ regulates the synthesis of $\gamma$-glutamyl transpeptidase and glutathione levels in rat primary astrocytes," Journal of Neurochemistry, vol. 73, no. 2, pp. 859866, 1999.

[129] S. Y. Lee, J. H. Chuang, C. C. Huang et al., "Identification of transforming growth factors actively transcribed during the progress of liver fibrosis in biliary atresia," Journal of Pediatric Surgery, vol. 39, no. 5, pp. 702-708, 2004.

[130] H. U. Baer, H. Friess, M. Abou-Shady et al., "Transforming growth factor betas and their receptors in human liver cirrhosis," European Journal of Gastroenterology and Hepatology, vol. 10, no. 12, pp. 1031-1039, 1998.

[131] B. S. Lee, N. J. Kim, H. Y. Jeong, H. Y. Lee, D. Y. Kang, and S. M. Noh, "Changes in serum cytokine concentration: a morphological study of liver cirrhosis induced by common bile duct ligation in rats," The Korean Journal of Internal Medicine, vol. 18, no. 1, pp. 6-12, 2003.

[132] J. Jia, M. Bauer, and G. Boigk, "Cloning of partial cDNA of rat connective tissue growth factor and expression of its mRNA in experimental liver fibrosis," Zhonghua Gan Zang Bing Za Zhi, vol. 8, no. 2, pp. 102-104, 2000 (Chinese).

[133] D. Wang, H. Zhang, J. Liang et al., "CD4+CD25+but not CD4+Foxp3+ $\mathrm{T}$ cells as a regulatory subset in primary biliary cirrhosis," Cellular and Molecular Immunology, vol. 7, no. 6, pp. 485-490, 2010.

[134] A. Voumvouraki, M. Koulentaki, M. Tzardi et al., "Increased TGF- $\beta 3$ in primary biliary cirrhosis: an abnormality related to pathogenesis?" World Journal of Gastroenterology, vol. 16, no. 40, pp. 5057-5064, 2010.

[135] O. M. Martinez, J. C. Villanueva, M. E. Gershwin, and S. M. Krams, "Cytokine patterns and cytotoxic mediators in primary biliary cirrhosis," Hepatology, vol. 21, no. 1, pp. 113-119, 1995.

[136] H. Robertson, J. A. Kirby, W. W. Yip, D. E. J. Jones, and A. D. Burt, "Biliary epithelial-mesenchymal transition in posttransplantation recurrence of primary biliary cirrhosis," Hepatology, vol. 45, no. 4, pp. 977-981, 2007.

[137] A. Tsikrikoni, D. S. Kyriakou, E. I. Rigopoulou et al., "Markers of cell activation and apoptosis in bone marrow mononuclear cells of patients with autoimmune hepatitis type 1 and primary biliary cirrhosis," Journal of Hepatology, vol. 42, no. 3, pp. 393399, 2005.

[138] K. Zachou, E. I. Rigopoulou, A. Tsikrikoni et al., "Autoimmune hepatitis type 1 and primary biliary cirrhosis have distinct bone marrow cytokine production," Journal of Autoimmunity, vol. 25, no. 4, pp. 283-288, 2005.

[139] M. Neuman, P. Angulo, I. Malkiewicz et al., "Tumor necrosis factor- $\alpha$ and transforming growth factor- $\beta$ reflect severity of liver damage in primary biliary cirrhosis," Journal of Gastroenterology and Hepatology, vol. 17, no. 2, pp. 196-202, 2002.

[140] E. Patsenker, Y. Popov, F. Stickel, A. Jonczyk, S. L. Goodman, and D. Schuppan, "Inhibition of integrin alphavbeta6 on cholangiocytes blocks transforming growth factor-beta activation and retards biliary fibrosis progression," Gastroenterology, vol. 135, no. 2, pp. 660-670, 2008.

[141] S. Isik, U. Ozuguz, Y. A. Tutuncu et al., "Serum transforming growth factor-beta levels in patients with vitamin D deficiency," European Journal of Internal Medicine, vol. 23, pp. 93-97, 2012.

[142] T. López, D. García, B. Ángel et al., "Association between Fok I vitamin D receptor (VDR) gene polymorphism and plasmatic concentrations of transforming growth factor- $\beta 1$ and interferon gamma in type 1 diabetes mellitus," Medicina Clinica, vol. 130, no. 3, pp. 81-84, 2008 (Spanish).

[143] J. K. Aschenbrenner, H. W. Sollinger, B. N. Becker, and D. A. Hullett, "1,25- $\left(\mathrm{OH}_{2}\right) \mathrm{D}_{3}$ alters the transforming growth factor $\beta$ 
signaling pathway in renal tissue," Journal of Surgical Research, vol. 100, no. 2, pp. 171-175, 2001.

[144] S. K. Halder, J. S. Goodwin, and A. Al-Hendy, "1,25-Dihydroxyvitamin $\mathrm{D}_{3}$ reduces TGF- $\beta 3$-induced fibrosis-related gene expression in human uterine leiomyoma cells," Journal of Clinical Endocrinology and Metabolism, vol. 96, no. 4, pp. E754E762, 2011.

[145] S. Seydel, A. Beilfuss, A. Kahraman et al., "Vitamin D ameliorates stress ligand expression elicited by free fatty acids in the hepatic stellate cell line LX-2," The Turkish Journal of Gastroenterology, vol. 22, pp. 400-407, 2011. 


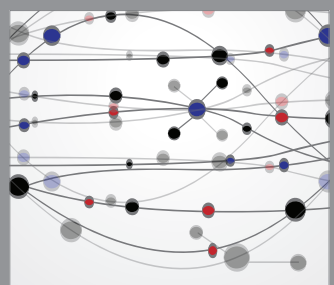

The Scientific World Journal
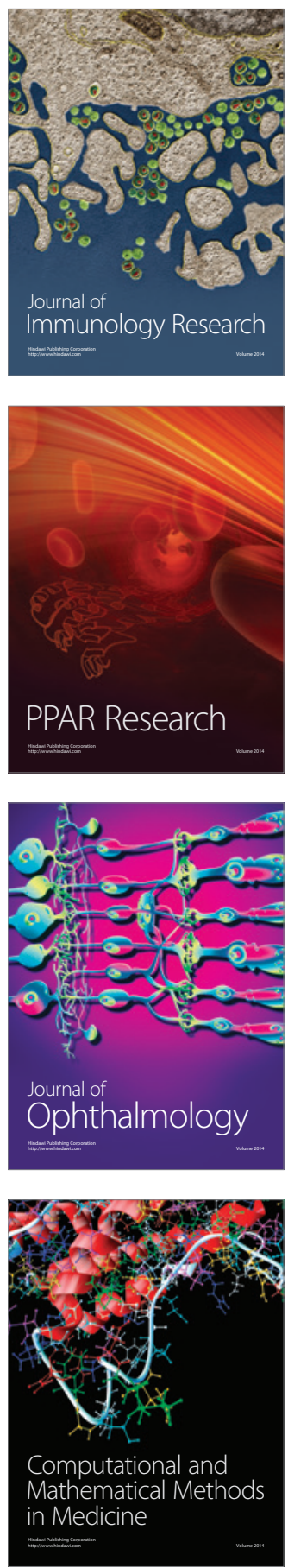

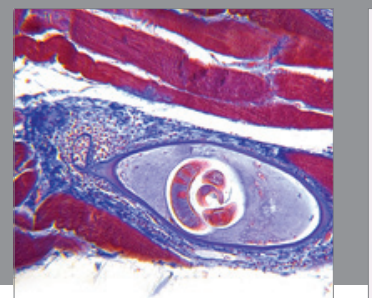

Gastroenterology

Research and Practice
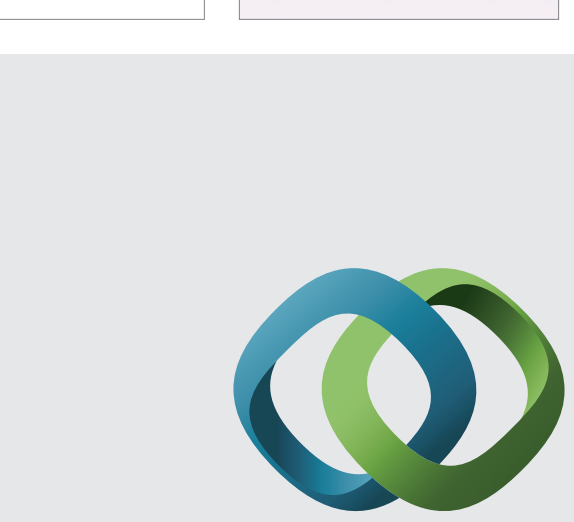

\section{Hindawi}

Submit your manuscripts at

http://www.hindawi.com
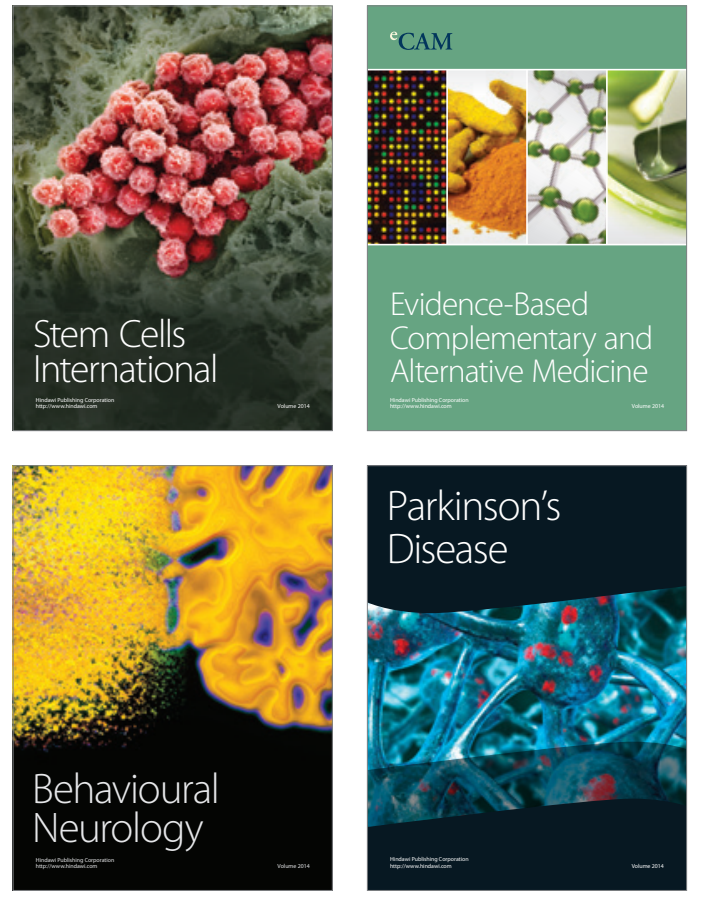
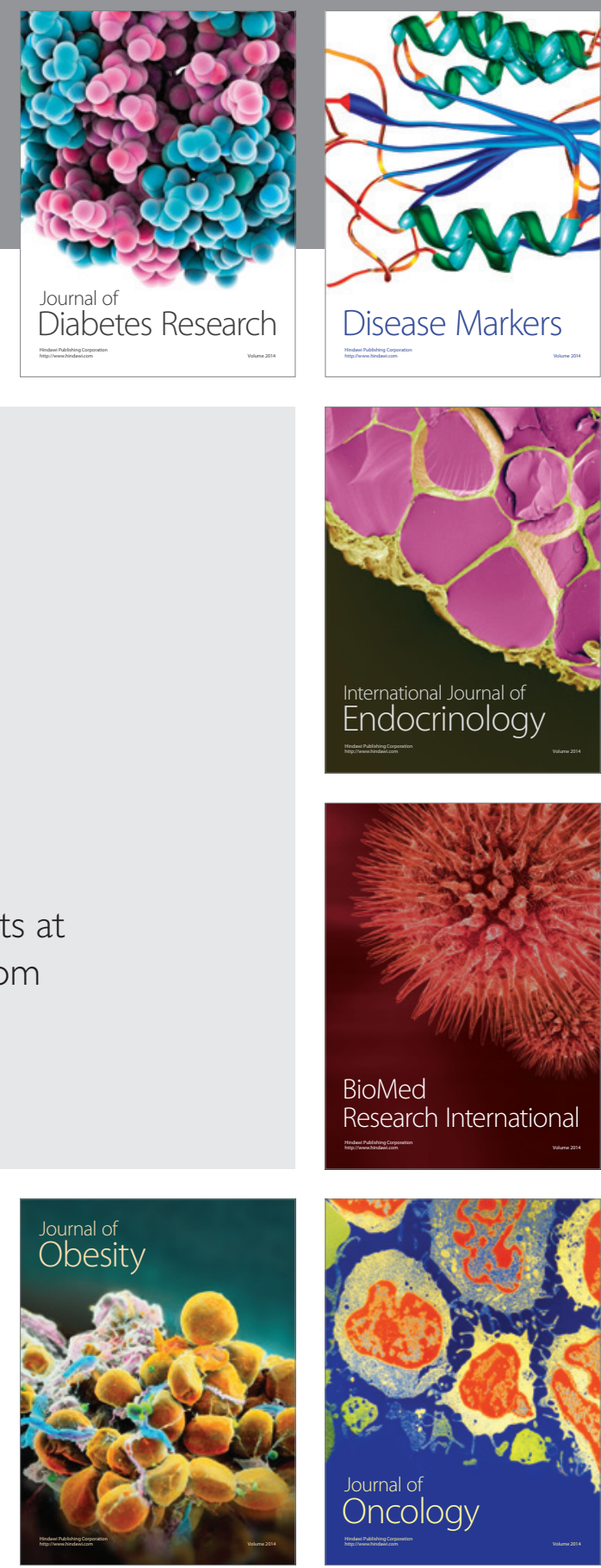

Disease Markers
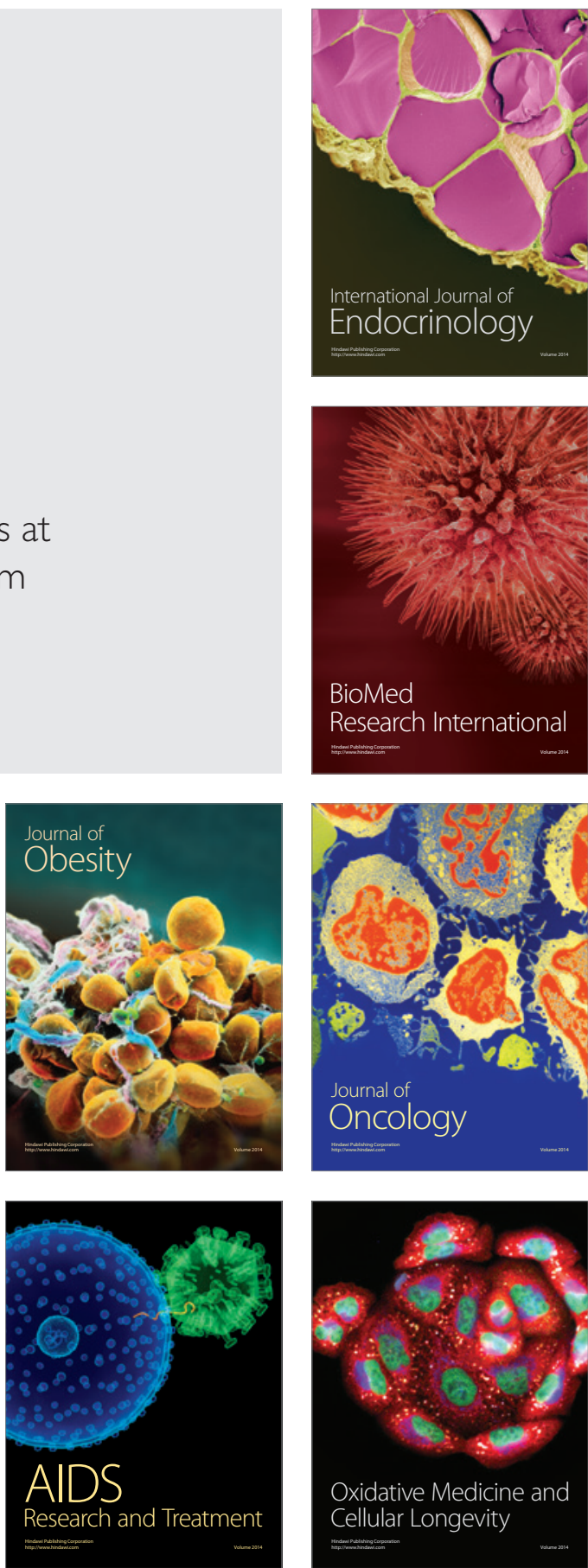